\title{
Reanalyzing Li and Tao. (2014): Investigating Algorithm Recognition on Dark Irises
}

\author{
Adebayo Omotosho \\ Dept. of Comp. Sc \& IT, Bells \\ University of Technology, \\ P.M.B 1015, Ota, Ogun State, \\ Nigeria.
}

\author{
Omotanwa Adegbola \\ Dept. of Comp. Sc \& IT, Bells \\ University of Technology, \\ P.M.B 1015, Ota, Ogun State, \\ Nigeria
}

\author{
Michael Edobor \\ Dept. of Comp. Sc \& IT, Bells \\ University of Technology, \\ P.M.B 1015, Ota, Ogun State, \\ Nigeria.
}

\begin{abstract}
Iris recognition algorithms have been proposed in several works with some of these algorithms solving mainly templates identification accuracy issues. The need to test these algorithms for identification or matching speed cannot be over-emphasized as this is also important when deploying algorithms in real application. This aim of this paper is to implement and validate a selected iris recognition algorithm. Performance evaluation was performed with the sole purpose of verifying the literature reported accuracy for the selected algorithm as well as to compute its identification speed on two databases (CASIA and BuIris) containing 600 iris images each. Results obtained matched the earlier $0 \%$ false acceptance with CASIA database but $42.3 \%$ with BuIris. This paper results verifies the scope of this algorithm and the need for improvement that could increase its adoptability globally.
\end{abstract}

\section{General Terms}

Algorithms

\section{Keywords}

Iris recognition; biometrics; empirical analysis; Casia; BuIris

\section{INTRODUCTION}

[1] define a biometrics as "a unique, measurable characteristic or trait of a human being for automatically recognizing or verifying identity". A Biometric is regarded as unique as it exists exclusively to an individual. The unique nature of biometrics has led to a rise in the development and application of identification and verification schemes [2, 3]. Some examples of biometrics identification methods include face recognition, fingerprint scanning, voice analysis, hand geometry, retinal scanning, signature recognition. The iris is an internal organ visible from the outside, meaning the pattern cannot be altered by external factors. Its unique features and complexity makes it good enough to be used as a biometric signature $[4,5,6,7]$.

The human iris colour plays an important role in determining how effective or accurate an algorithm can be. The human iris is the circular structure and may differ colour depending on the ethnicity of individual or genetic traits as different races often have different eye colors [8]. For example, most people of African descent have brown either light, dark, or brown irises while Caucasians may have either blue, grey or green irises. It has been observed that dark brown irises do not provide enough features that can be extracted if the image was taken using Visible Length imaging, unlike lighter iris colors that can be easily distinguished. Near Infrared Cameras or sensors is therefore used to capture iris images so that the system can be able to efficiently extract the iris features' from the image. Failure to correctly capture an iris under the required specifications and amount of illumination may give rise to problems in the segmentation phase and generally affect the overall performance of the system [9].

Iris recognition is a means of identifying individuals based on distinctive patterns of the iris $[10,11]$. It involves capturing an image of the individual's iris, processing the image and simply checking existing database entries for matches as a step of verification or authentication. Iris recognition systems are already in operation worldwide, including an expellee tracking system in the United Arab Emirates, a welfare distribution program for Afghan refugees in Pakistan, and potential applications include ticketless travel, premises access control into home, office, laboratory, and others [6]. Owing to its high reliability, it has also been proposed for animals' identification $[12,13]$. It is incontrovertible that iris recognition system is the most accurate biometrics system after DNA $[14,15,16]$.

Iris recognition systems encounter difficulties in reading irises of individuals with cataracts in their eyes or blind individuals. Also the cameras require a sufficient amount of Illumination to effectively capture iris images. Some of these problems can be tackled while some cannot. Most of the existing works are on iris recognition accuracy $[17,18,19]$ on non-African datasets, some of them are summarized in Table 1. This paper focused on the recognition and process speed of iris algorithm besides accuracy. The performance of an existing algorithm will be studied in a different way through the use of different iris database. This research is necessary as most users may be non-cooperative $[20,7]$ and an accurate system would be rated low on users experience in a practical environment with large number of subjects [21].

\section{METHODOLOGY}

[43] algorithm was selected based on the methods used in different phases in iris recognition and the way they addressed issues with existing algorithms. Another reason is because it gave a very high average recognition accuracy of $96.5 \%$ and operational running time of 2.1 seconds. [43] method for iris recognition system uses an improved compressive sensing algorithm to achieve quick identification of iris. Extraction of iris image edge point was done using canny operator and then Hough transform was used to fit the two boundaries of the iris. The iris region is clipped, compressive sensing algorithm then is used to recognize categories of irises. Their algorithm was evaluated using metrics like False Acceptance Rate, False 
Table 1. Review of existing iris recognition algorithms

\begin{tabular}{|c|c|c|c|c|}
\hline Author & Summary & Method/ Algorithm & Results & $\begin{array}{l}\text { Limitations/Future } \\
\text { Works }\end{array}$ \\
\hline [22] & $\begin{array}{l}\text { Paper presents a non-invasive iris } \\
\text { recognition system. This system } \\
\text { does not require subjects to make } \\
\text { contact with the camera or be too } \\
\text { close to the camera for image } \\
\text { acquisition and verification. }\end{array}$ & $\begin{array}{l}\text { Using vision and control } \\
\text { algorithms, a stereo pair of } \\
\text { wide field-of-view (WFOV) } \\
\text { cameras, a narrow field-of- } \\
\text { view (NFOV), Daugman's } \\
\text { system for further processing. }\end{array}$ & $\begin{array}{l}\text { Average verification } \\
\text { time of a subject is } \\
5.5 \text { seconds. }\end{array}$ & $\begin{array}{l}\text { Specularities off the } \\
\text { frames of glasses (Eye } \\
\text { glasses) result in false } \\
\text { eye detection and errors. } \\
\text { In future work, } \\
\text { Optimization of } \\
\text { algorithms and } \\
\text { movement of camera } \\
\text { would help in reducing } \\
\text { the operational time. }\end{array}$ \\
\hline$[23]$ & $\begin{array}{l}\text { This work basically entails an } \\
\text { algorithm which is translation, } \\
\text { rotation, and scale invariant. It aims } \\
\text { at improving the feature extraction } \\
\text { phase of Iris recognition. }\end{array}$ & $\begin{array}{l}\text { Uses the zero crossings of the } \\
\text { wavelet transform of the } \\
\text { unique features obtained from } \\
\text { the grey-level profiles of the } \\
\text { iris. }\end{array}$ & $\begin{array}{l}\text { It is computationally } \\
\text { efficient and less } \\
\text { sensitive to noise and } \\
\text { quantization } \\
\text { errors. }\end{array}$ & \\
\hline [24] & $\begin{array}{l}\text { This paper is focused on } \\
\text { performance improvement of Iris } \\
\text { recognition system. A performance } \\
\text { evaluation is carried out on popular } \\
\text { feature extraction methods like } \\
\text { Gabor Transform and Wavelet } \\
\text { Transform in order to choose a more } \\
\text { suitable method for Iris Pattern } \\
\text { Recognition. }\end{array}$ & $\begin{array}{l}\text { Using wavelet transform, } \\
\text { weight vector initialization and } \\
\text { winner } \\
\text { Selection, Competitive } \\
\text { Learning Neural Network }\end{array}$ & $\begin{array}{l}\text { Haar wavelet } \\
\text { transform has better } \\
\text { performance than that } \\
\text { of Gabor transform in } \\
\text { feature extraction and } \\
\text { the Processing time } \\
\text { from Data acquisition } \\
\text { to } \\
\text { Identification/Identifi } \\
\text { cation is about } 2 \\
\text { seconds. Increased } \\
\text { recognition } \\
\text { performance of } \\
98.4 \% \text { a }\end{array}$ & \\
\hline [25] & $\begin{array}{l}\text { This proposed algorithm extracts } \\
\text { both globaland local information of } \\
\text { the iris. Each iris image is } \\
\text { Filtered with Gabor filters and then } \\
\text { a fixed length feature vector is } \\
\text { obtained. }\end{array}$ & $\begin{array}{l}\text { Uses multichannel Gabor } \\
\text { filtering }\end{array}$ & $\begin{array}{l}\text { Results shows that the } \\
\text { algorithm can } \\
\text { effectively distinguish } \\
\text { different persons by } \\
\text { identifying their irises } \\
\text { and also } \\
\text { computationally } \\
\text { efficient and } \\
\text { insensitive } \\
\text { illumination } \\
\text { noise. and }\end{array}$ & $\begin{array}{l}\text { Future works will focus } \\
\text { on more iris features and } \\
\text { image sequences. }\end{array}$ \\
\hline [10] & $\begin{array}{l}\text { This paper deals with image } \\
\text { processing algorithms that would } \\
\text { improve the recognition rate of iris } \\
\text { recognition systems. }\end{array}$ & $\begin{array}{l}\text { Gradient decomposed hough } \\
\text { transform/ integro-differential } \\
\text { operators combination for iris } \\
\text { localization and } \\
\text { 2D Hilbert transform to extract } \\
\text { textural iris information. }\end{array}$ & $\begin{array}{l}\text { A total processing } \\
\text { time of } 450 \mathrm{~ms} \text { was } \\
\text { calculated after } \\
\text { implementation in } \mathrm{C} \text {. }\end{array}$ & $\begin{array}{l}\text { Experimental results } \\
\text { were obtained on a small } \\
\text { number of iris images } \\
\text { and not on a large data } \\
\text { set so the results cannot } \\
\text { fully be depended on. }\end{array}$ \\
\hline [26] & $\begin{array}{l}\text { This paper proposes the use of } \\
\text { Phase based matching to create an } \\
\text { efficient Iris recognition system. }\end{array}$ & $\begin{array}{l}\text { Phase components are used in } \\
\text { the 2D discrete fourier } \\
\text { transforms of the image }\end{array}$ & $\begin{array}{l}\text { After tests on low } \\
\text { quality images from } \\
\text { the CASIA database, } \\
\text { the algorithm yielded }\end{array}$ & $\begin{array}{l}\text { Method to be applied } \\
\text { mostly in multi-modal } \\
\text { biometric systems that } \\
\text { comprises of both Iris }\end{array}$ \\
\hline
\end{tabular}




\begin{tabular}{|c|c|c|c|c|}
\hline & & & $\begin{array}{l}\text { an EER (Equal error } \\
\text { rate) of } 0.58 \% \text {. }\end{array}$ & $\begin{array}{l}\text { and fingerprint } \\
\text { recognition capabilities. }\end{array}$ \\
\hline [27] & $\begin{array}{l}\text { Different approaches were } \\
\text { proposed and used namely gabor } \\
\text { filters and zero crossing } \\
\text { Representations of a discrete dyadic } \\
\text { wavelet transform. This approaches } \\
\text { were tested with three different } \\
\text { pattern recognition methods }\end{array}$ & $\begin{array}{l}\text { Using Gabor filters, Hamming } \\
\text { distance and zero crossing } \\
\text { discrete dyadic } \\
\text { transform. }\end{array}$ & $\begin{array}{l}\text { Classification success } \\
\text { of } 99.6 \% \text { and EER of } \\
0.12 \% \text {. }\end{array}$ & $\begin{array}{l}\text { Lack of a huge database } \\
\text { to extensively test } \\
\text { approaches. }\end{array}$ \\
\hline$[28]$ & $\begin{array}{l}\text { This paper present an iris coding } \\
\text { method based on differences of } \\
\text { discrete cosine transform (DCT) } \\
\text { coefficients of overlapped angular } \\
\text { patches from normalized iris } \\
\text { images. }\end{array}$ & $\begin{array}{l}\text { Approach using 1D Discrete } \\
\text { Cosine Transform (DCT) }\end{array}$ & 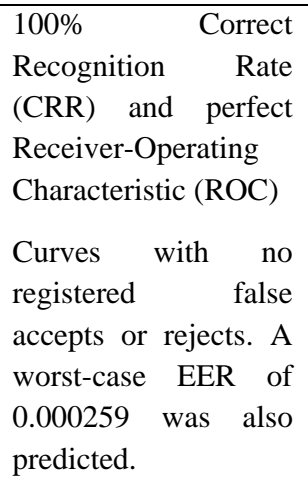 & $\begin{array}{l}\text { Method was not tested on } \\
\text { large datasets due to } \\
\text { security or proprietary } \\
\text { reasons }\end{array}$ \\
\hline [29] & $\begin{array}{l}\text { This paper proposes algorithms for } \\
\text { iris segmentation, quality } \\
\text { enhancement, match score fusion, } \\
\text { and indexing to improve both the } \\
\text { accuracy and speed of iris } \\
\text { recognition. }\end{array}$ & $\begin{array}{l}\text { Using modified Mumford-Shah } \\
\text { functional, 1D log polar Gabor } \\
\text { transform, Euler numbers. }\end{array}$ & $\begin{array}{l}\text { Produces an overall } \\
\text { recognition accuracy } \\
\text { of } 99.93 \%\end{array}$ & \\
\hline [30] & $\begin{array}{l}\text { This paper proposes a method of } \\
\text { improving performance of iris } \\
\text { identification and verification while } \\
\text { taking into consideration the } \\
\text { anomalies which may occur during } \\
\text { image capture. }\end{array}$ & $\begin{array}{l}\text { Using modified Mumford-Shah } \\
\text { functional, 1D log polar Gabor } \\
\text { transform, Euler numbers. }\end{array}$ & $\begin{array}{l}\text { Reduces the False } \\
\text { rejection rate for } \\
\text { verification and the } \\
\text { computational time } \\
\text { without affecting the } \\
\text { identification } \\
\text { accuracy. } \\
\text { Combination of } \\
\text { methods in paper } \\
\text { gives an identification } \\
\text { accuracy of } 97.21 \% \\
\text { in } 1.82 \mathrm{secs}\end{array}$ & $\begin{array}{l}\text { It adds unwanted artifacts } \\
\text { to the high quality area of } \\
\text { the iris image. It is also } \\
\text { very difficult to enhance } \\
\text { only selected regions of } \\
\text { the image. }\end{array}$ \\
\hline [31] & $\begin{array}{l}\text { This proposed algorithm localizes } \\
\text { both iris boundaries and detects } \\
\text { eyelids then Daugman's integro- } \\
\text { differential operator is applied }\end{array}$ & $\begin{array}{l}\text { Daugman's integro-differential } \\
\text { operator }\end{array}$ & $\begin{array}{l}\text { Better performance in } \\
\text { both recognition and } \\
\text { iris segmentation. An } \\
\text { iris localization time } \\
\text { of } 0.95 \mathrm{secs}\end{array}$ & \\
\hline [32] & $\begin{array}{l}\text { Paper projects a detailed analysis of } \\
\text { the effects of contact lens(colored } \\
\text { lens and transparent) on Iris } \\
\text { recognition performance and also } \\
\text { recommends the use of Lens } \\
\text { recognition algorithms }\end{array}$ & $\begin{array}{l}\text { IIIT-D CLI1 database and } \\
\text { VeriEye software were both } \\
\text { used to evaluate the iris } \\
\text { recognition } \quad \text { system's } \\
\text { performances on various } \\
\text { images. Existing lens detection } \\
\text { algorithms are also used to test } \\
\text { iris verification performance }\end{array}$ & $\begin{array}{l}\text { On application of a } \\
\text { lens detection } \\
\text { algorithm, the } \\
\text { recognition accuracy } \\
\text { improves to } 94.41 \% \text {. } \\
\text { However, removal of } \\
\text { the contact lens } \\
\text { would increase } \\
\text { recognition accuracy. }\end{array}$ & $\begin{array}{l}\text { Less Accurate lens } \\
\text { detection algorithms } \\
\text { gives rise for a need to } \\
\text { develop more } \\
\text { sophisticated contact lens } \\
\text { detection algorithms in } \\
\text { order to improve } \\
\text { recognition accuracy. }\end{array}$ \\
\hline
\end{tabular}




\begin{tabular}{|c|c|c|c|c|}
\hline [33] & $\begin{array}{l}\text { This study employs artificial } \\
\text { intelligence and effective methods } \\
\text { in feature extraction to result in an } \\
\text { effect iris recognition system. }\end{array}$ & $\begin{array}{l}\text { Discrete cosine transform is } \\
\text { used for feature extraction and } \\
\text { artificial neural networks for } \\
\text { Classification. }\end{array}$ & $\begin{array}{l}96 \% \text { recognition } \\
\text { accuracy with low } \\
\text { computational costs. }\end{array}$ & \\
\hline [34] & $\begin{array}{l}\text { Paper is about the design and } \\
\text { implementation of a long distance } \\
\text { iris recognition system that can } \\
\text { capture and process images within } \\
30 \text { meters. Also introduces a IAAD } \\
\text { (Iris at a Distance) system. }\end{array}$ & $\begin{array}{l}\text { Uses Daugman Algorithm, } \\
\text { Telescope and a Wide field of } \\
\text { View Camera. }\end{array}$ & $\begin{array}{l}\text { This system gives a } \\
\text { Hamming distance } \\
\text { threshold of } 0.33 \text {. }\end{array}$ & $\begin{array}{l}\text { The small nature of the } \\
\text { Iris becomes a challenge } \\
\text { in image acquisition as } \\
\text { images may not be clear } \\
\text { enough for recognition. } \\
\text { Because of the distance, } \\
\text { techniques like Face } \\
\text { Recognition, Focus } \\
\text { Control and Image } \\
\text { stabilization should be } \\
\text { incorporated in the Iris } \\
\text { recognition system to } \\
\text { yield better results. }\end{array}$ \\
\hline [35] & $\begin{array}{l}\text { This paper describes a technique for } \\
\text { implementing a wireless class } \\
\text { attendance system using Iris } \\
\text { recognition. }\end{array}$ & Using Daugman's Algorithm. & $\begin{array}{l}\text { This method yields a } \\
\text { verification rate of } \\
98.3 \% \text { and a rejection } \\
\text { rate of } 9.2 \% \text {. }\end{array}$ & $\begin{array}{l}\text { RFID technology and } \\
\text { other biometrics } \\
\text { technologies like retinal } \\
\text { verifying should be } \\
\text { worked on to enhance the } \\
\text { reliability of recognition } \\
\text { and adopt new wireless } \\
\text { technologies. }\end{array}$ \\
\hline$[36]$ & $\begin{array}{l}\text { This paper describes how a very fast } \\
\text { iris recognition system can be } \\
\text { implemented with a small template } \\
\text { size to enable applications in small } \\
\text { embedded systems. }\end{array}$ & $\begin{array}{l}\text { Wavelet transform is used for } \\
\text { feature extraction and Haal } \\
\text { wavelet is also used as a } \\
\text { mother wavelet. }\end{array}$ & $\begin{array}{l}\text { A CRR of } 99 \% \text { was } \\
\text { achieved on a set of } \\
\text { samples from CASIA } \\
\text { database. } 0 \% \text { FAR } \\
\text { and } 1 \% \text { FRR were } \\
\text { also achieved. } \\
\text { Less computational } \\
\text { complexity. }\end{array}$ & \\
\hline [37] & $\begin{array}{l}\text { Paper presents a new iris } \\
\text { identification algorithm that is } \\
\text { highly reliable. }\end{array}$ & $\begin{array}{l}\text { Uses pattern-recognition } \\
\text { techniques based on high- } \\
\text { resolution images of the irides } \\
\text { of an individual's eye, IER (Iris } \\
\text { Effective Region) feature } \\
\text { extraction used for pattern } \\
\text { matching was compared with } \\
\text { the stored patterns within the } \\
\text { database. }\end{array}$ & $\begin{array}{l}\text { Proposed method } \\
\text { gives a FAR of } 2 \% \\
\text { and FRR of } 0 \%\end{array}$ & $\begin{array}{l}\text { More research in Diverse } \\
\text { environments and } \\
\text { configuration needs to be } \\
\text { carried out. This } \\
\text { algorithm cannot } \\
\text { efficiently handle noisy } \\
\text { or degraded images. }\end{array}$ \\
\hline [9] & $\begin{array}{l}\text { This paper presents the acquisition } \\
\text { of eye-iris images of dark-skinned } \\
\text { subjects in Africa, a predominant } \\
\text { case of very-dark-brown iris images, } \\
\text { under near-infrared illumination. Its } \\
\text { aim was to create a dark-iris dataset }\end{array}$ & $\begin{array}{l}\text { They created a dataset by } \\
\text { capturing iris images of } \\
\text { students in covenant university, } \\
\text { Nigeria. }\end{array}$ & $\begin{array}{l}\text { Total of } 162 \text { images } \\
\text { was captured from } 81 \\
\text { subjects }\end{array}$ & $\begin{array}{l}\text { Limited number of } \\
\text { images and a small } \\
\text { dataset. } \\
\text { It wasn't tested on } \\
\text { multiple algorithms. }\end{array}$ \\
\hline$[38]$ & $\begin{array}{l}\text { This paper proposes a recognition } \\
\text { system with the use artificial } \\
\text { intelligence. }\end{array}$ & $\begin{array}{l}\text { Back Propagating Neural } \\
\text { Network. }\end{array}$ & $\begin{array}{ll}\text { Algorithm } & \text { gives a } \\
\text { recognition } & \text { accuracy } \\
\text { of } 99.25 \% \text {. } & \end{array}$ & \\
\hline [39] & $\begin{array}{l}\text { A new algorithm for feature } \\
\text { extraction which reduces the effect }\end{array}$ & $\begin{array}{l}\text { RED (Ridge Edge Detection) } \\
\text { algorithm. }\end{array}$ & $\begin{array}{l}\text { Claims to have a FRR } \\
\text { of } 0 \% \text { and recognition }\end{array}$ & $\begin{array}{l}\text { May not give optimal } \\
\text { results when processing }\end{array}$ \\
\hline
\end{tabular}




\begin{tabular}{|c|c|c|c|c|}
\hline & $\begin{array}{l}\text { of illumination on iris images and } \\
\text { improves the accuracy of an iris } \\
\text { recognition system is proposed. }\end{array}$ & & $\begin{array}{lr}\text { accuracy of } & 100 \% . \\
\text { Operates properly in a } \\
\text { noise } & \text { free } \\
\text { environment } & \end{array}$ & noisy images. \\
\hline$[40]$ & $\begin{array}{l}\text { This paper is centered on the } \\
\text { improvement of the Iris } \\
\text { segmentation phase in order to } \\
\text { increase accuracy of an Iris } \\
\text { recognition system }\end{array}$ & $\begin{array}{l}\text { Using Daugman's } \\
\text { segmentation algorithm and } \\
\text { Daugman's. } \\
\text { Rubber Sheet Model, 1D Log- } \\
\text { Gabor filters }\end{array}$ & $\begin{array}{l}\text { Daugman's } \\
\text { Algorithm based } \\
\text { segmentation } \\
\text { technique managed to } \\
\text { correctly segment the } \\
\text { iris region from } 3 \text { out } \\
\text { of } 4 \text { eye images, } \\
\text { which corresponds to } \\
\text { a success rate of } \\
\text { around } 83 \% \text {. }\end{array}$ & $\begin{array}{l}\text { Addition of an eyelid } \\
\text { detection system reduced } \\
\text { the accuracy of the } \\
\text { recognition system. }\end{array}$ \\
\hline$[41]$ & $\begin{array}{l}\text { This paper proposes an iris image } \\
\text { matching and recognition method } \\
\text { based on local mean decomposition } \\
\text { (LMD). }\end{array}$ & $\begin{array}{l}\text { Using Local Mean } \\
\text { Decomposition }\end{array}$ & $\begin{array}{l}\begin{array}{l}\text { Euclidean distances } \\
\text { measure (MED) } \\
\text { similarity measure }\end{array} \\
\text { achieves a CRR up to } \\
\text { 100\% when tested on } \\
\text { CASIA database and } \\
244 \text { classes of ICE } \\
\text { Database iris. }\end{array}$ & $\begin{array}{l}\text { Usage of noncircular } \\
\text { models for the iris image } \\
\text { boundaries r could } \\
\text { improve the accuracy of } \\
\text { the system. }\end{array}$ \\
\hline [42] & $\begin{array}{l}\text { Paper proposes a new technique for } \\
\text { iris recognition }\end{array}$ & $\begin{array}{l}\text { Using image moments, k- } \\
\text { means algorithm, Neural } \\
\text { Networks }\end{array}$ & $\begin{array}{l}\text { This model exhibits } \\
\text { an accuracy of } 98.5 \%\end{array}$ & \\
\hline [43] & $\begin{array}{l}\text { Paper proposes a highly robust } \\
\text { algorithm which greatly reduces } \\
\text { operational time and increases the } \\
\text { recognition accuracy of the system. }\end{array}$ & $\begin{array}{l}\text { Compressive } \text { Sensing } \\
\text { Algorithm, Gabor filters with } \\
\text { Principal Component Analysis } \\
\text { (GCPA), Orthogonal Matching } \\
\text { Pursuit algorithm. }\end{array}$ & $\begin{array}{l}\text { It gave an average } \\
\text { recognition accuracy } \\
\text { of } 96.5 \% \text { and } \\
\text { operational Running } \\
\text { time of } 2.1 \text { seconds. }\end{array}$ & \\
\hline [44] & $\begin{array}{l}\text { The main idea behind this paper is } \\
\text { to recognize an individual by } \\
\text { comparing his/her iris features with } \\
\text { an iris feature database. }\end{array}$ & $\begin{array}{l}\text { Using Complex Dual-Tree } \\
\text { Discrete Wavelet Transform(C- } \\
\text { DT-DWT) and both Irises of an } \\
\text { individual to improve } \\
\text { recognition rate }\end{array}$ & $\begin{array}{l}\text { A mismatch rate of } \\
92.25 \% \text { was obtained } \\
\text { after comparison of } \\
\text { both irises of an } \\
\text { individual. }\end{array}$ & \\
\hline$[45]$ & $\begin{array}{l}\text { Proposes an iris recognition } \\
\text { algorithm that not only considers the } \\
\text { iris texture curve features, but also } \\
\text { eliminates the influence of } \\
\text { environment noise and reduces the } \\
\text { feature dimension leading to a very } \\
\text { effective system }\end{array}$ & $\begin{array}{l}\text { Methods used include Curvelet, } \\
\text { Principal Component Analysis } \\
\text { (PCA) and Linear Discriminant } \\
\text { Analysis(LDA) }\end{array}$ & $\begin{array}{l}\text { The proposed method } \\
\text { gave an average } \\
\text { recognition rate of } \\
96.30 \% \text { when tested } \\
\text { with } 9 \text { normalized } \\
\text { samples of each } \\
\text { individual. }\end{array}$ & \\
\hline
\end{tabular}

Rejection Rate, Equal Error Rate, Failure to Enroll, Gray Density Function and the overall speed (seconds).

In our case, tests were carried out on image samples taken in uncontrolled environments using a high quality iris scanner since one of the problems with most iris recognition systems is poor robustness. The captured images were uploaded into the implemented algorithm and the system output results based on similar metrics. Fig 1 shows the illustration of how the implemented the system operates.

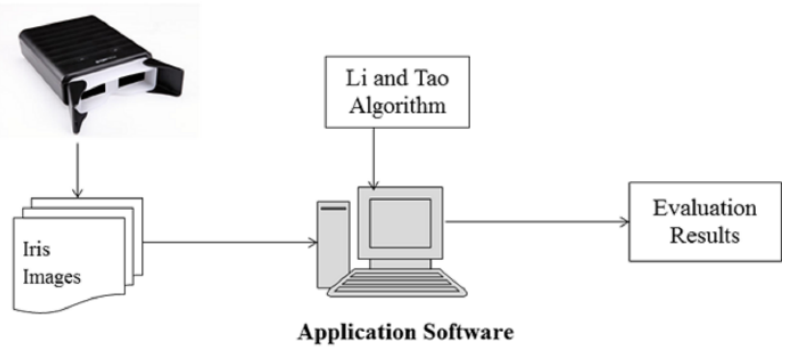

Figure 1:Implemented system operation 


\subsection{BuIris: The Dark-Skinned African Iris Dataset}

The introductory version of the African iris dataset, called BuIris, is presented in this section.

\subsubsection{Image Data Source and Data Description}

The images were acquired from 300 subjects drawn from the community of Bells University of Technology, Nigeria. The left and right irises of each subject were captured at a close range, in a single session, resulting in 600 eye-iris images in bitmap format.

\subsubsection{Acquisition Device and Acquisition Method} The eye-iris images were acquired and digitized by the CMITech BMT 20 dual iris scanner, shown in Fig 2. The scanner captures the right and left irises concurrently and this whole process takes less than a second to complete with full cooperation of the subjects.

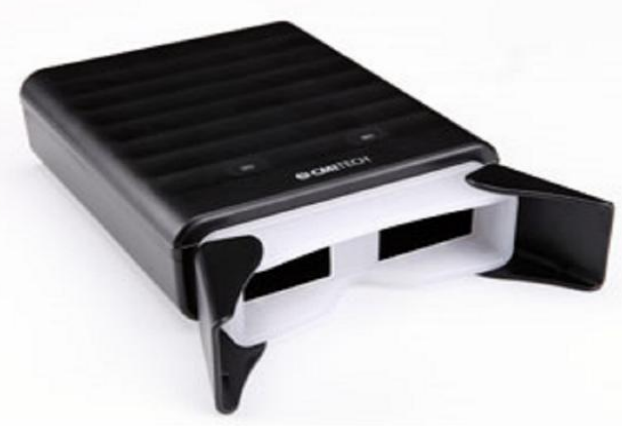

Figure 2: CmiTech BMT 20 Dual Iris Scanner

Some of the specifications of the iris scanner are summarized in Table 2. Proper quality assessment, and iris segmentation which is integrated in the device SDK, ensures the iris is very visible before capturing the image. The image output also meets or exceeds the ISO 19794-6 standard. The iris scanner was connected to a PC via a USB port and operated in the manual capture mode. Environmental condition, lighting was not controlled in order to simulate a real life scenario.

Table 2. CmiTech BMT 20 Iris Scanner specifications

\begin{tabular}{|r|l|l|}
\hline \multicolumn{1}{|l|}{ S/N } & Attributes & Specifications \\
\hline 1. & Iris scanner & Dual Iris scanner \\
\hline 2. & Pixel Resolution & 18.4 to 20 pixels/mm \\
\hline 3. & Spatial Resolution & $\begin{array}{l}\text { Exceeds 4.0 lp/mm @ > } \\
60 \% \text { contrast }\end{array}$ \\
\hline 4. & Eye Safety Standard & IEC 62471, IEC 60825-1 \\
\hline 5. & $\begin{array}{l}\text { Inter-pupillary } \\
\text { distance covered }\end{array}$ & $\begin{array}{l}40 \text { to 90mm (1.6 to 3.5 } \\
\text { inches) }\end{array}$ \\
\hline 6. & $\begin{array}{l}\text { IR Illumination for } \\
\text { Iris Imaging }\end{array}$ & $\begin{array}{l}\text { Dual LED: wavelengths } \\
\text { of 850 nm nominal } \\
\text { (about 60\%); and 750 nm } \\
\text { nominal (about 40\%) }\end{array}$ \\
\hline
\end{tabular}

\section{RESULTS}

Two of the important application interface of the system are shown in Fig 3 and Fig 4. Table 3 shows the parameters used in evaluating [43] algorithm and the results obtained. The result is close to the high average recognition accuracy of 96.5\% obtained in the original algorithm when tested with CASIA database. Testing with BuIris images led to a higher False Acceptance Rate which represents a problem if [43] algorithm was to be generally adopted. Comparatively, the failure to enroll rate for BuIris images is also high. Table 4 compares the histogram of a BuIris and a CASIA image using 30 samples each from the two datasets; rich information area falls between $20-170$ gray levels for the BuIris and $70-256$ gray levels for CASIA.

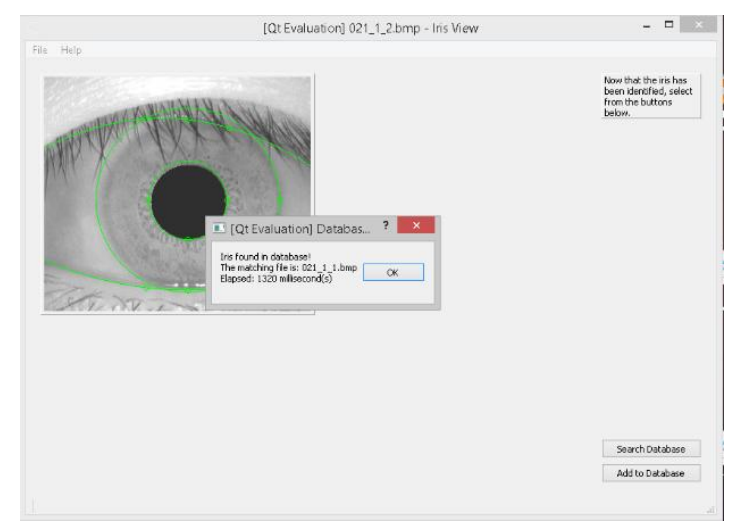

Figure 3: Application's User Interface (Showing matching time)

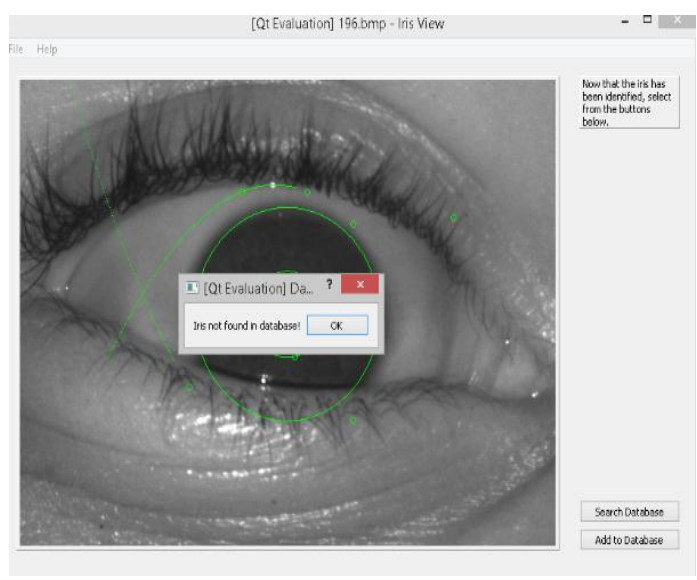

Figure 4: Application's user interface (When an Iris has not been enrolled). 
Table 3. Tabular comparison of results on both BuIris and CASIA Images

\begin{tabular}{|l|l|l|l|l|l|l|l|}
\hline Database & $\begin{array}{l}\text { Number of } \\
\text { Images }\end{array}$ & $\begin{array}{l}\text { Image } \\
\text { Format }\end{array}$ & Image Dimension & $\begin{array}{l}\text { Average } \\
\text { Matching Time } \\
\text { (Secs) }\end{array}$ & $\begin{array}{l}\text { False } \\
\text { Acceptance } \\
\text { Rate( \%) }\end{array}$ & $\begin{array}{l}\text { False } \\
\text { Rejection } \\
\text { Rate }(\boldsymbol{\%})\end{array}$ & $\begin{array}{l}\text { Failure } \\
\text { Enroll } \\
(\%)\end{array}$ \\
\hline RASIA & 600 &.$b m p$ & $320 * 280$ pixels & 0.8515 & 0 & 0 & 0 \\
\hline BuIris & 600 &.$b m p$ & $320 * 280$ pixels & 0.5379 & 42.3 & 2.16 & $8.16 \%$ \\
\hline
\end{tabular}

Table 4. Histogram of selected images from BuIris and CASIA

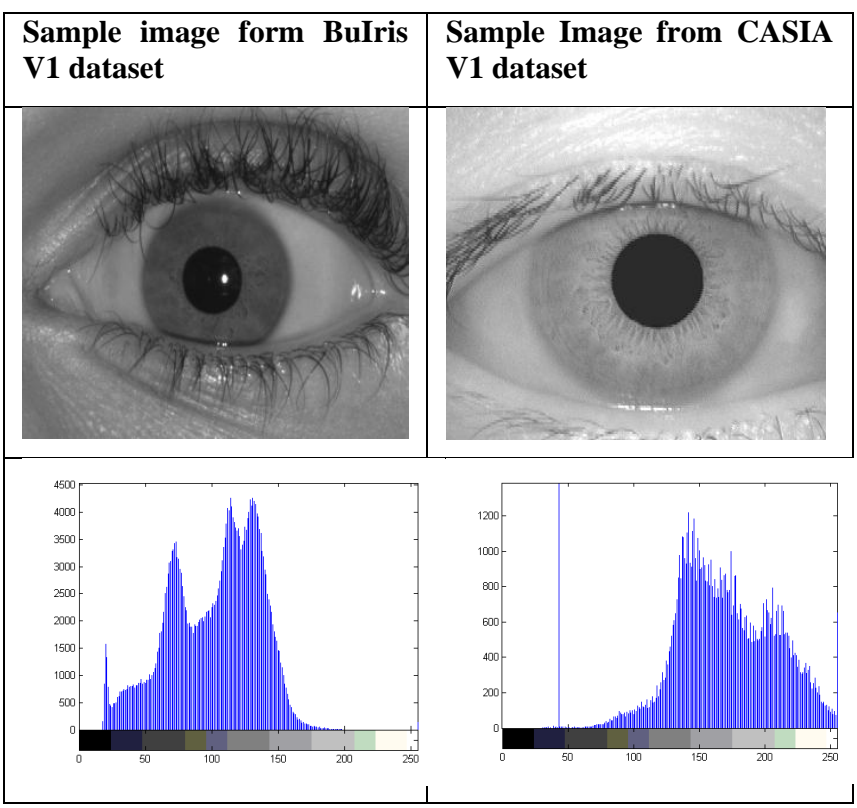

Graphs in Fig 5 and Fig 6 shows the relationship between the number of CASIA V1/BuIris images tested and the corresponding matching time(s). When the two dataset results are compared there was a clear difference in their matching time as the size of the images increases. The drops in BuIris denote the number of enrollment failures, some of which can be attributed to system error or inability to detect the iris in the image.

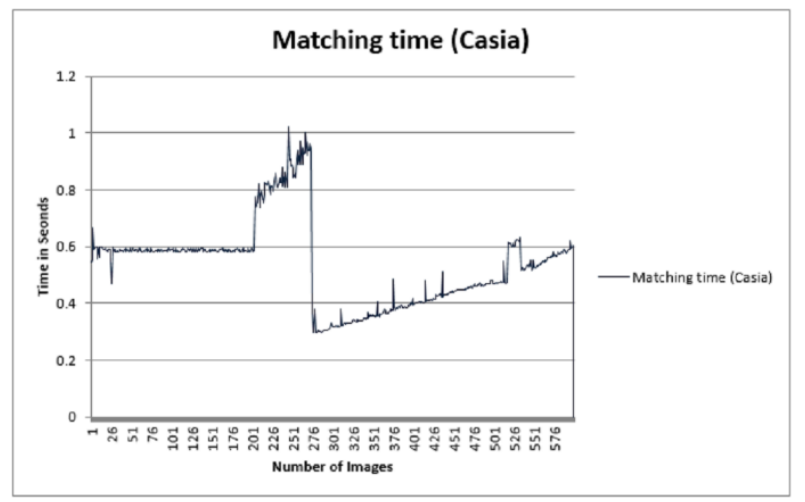

Figure 5: Graph showing matching time of CASIA against number of images $(600)$

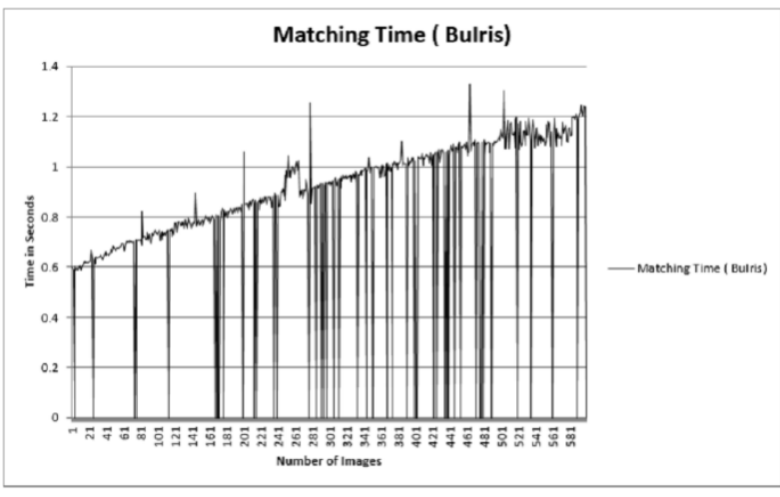

Figure 6: Graph showing matching time of BUIris against number of images (600)

\section{CONCLUSION}

There is a need to deploy highly efficient iris recognition algorithm due to the criticality and importance of a biometric security application. With the knowledge gained from this paper, it was found out that the selected algorithm performs efficiently when tested with images from a public database (CASIA). However, the algorithm does not perform effectively when processing iris images with dark irises and also the matching time increases as the size of the image increases.

The creation of a BuIris dataset which would also be made public could aid researchers with more training or testing datasets when developing algorithms that would function more accurately on people with dark brown irises. Future works would focus on improving this algorithm so that it would work effectively with dark irises because this would further help increase the adoption of iris recognition.

\section{REFERENCES}

[1] Wang L, Geng X. Behavioral biometrics for human identification: Intelligent applications. Hershey, PA: IGI Global; 2010.

[2] Bakshi S, Mehrotra H, Majhi B. Postmatch pruning of SIFT pairs for iris recognition. International Journal of Biometrics. 2013; 5(2):160-80.

[3] Kindt E. Privacy and data protection issues of biometric applications. Law, Governance and Technology Series. 2013; 12.

[4] Wildes RP. Iris recognition: an emerging biometric technology. Proceedings of the IEEE. 1997; 85(9):134863.

[5] Fakhry HH, Cardozo BB. Research and Development of an Iris-Based Recognition System for Identification and Secure Authentication. INFORMATION AND SECURITY. 2006; 19:39.

[6] Ross A. Iris recognition: The path forward. Computer. 2010; 43(2):30-5. 
[7] Yang K, Du EY. Speed-up multi-stage non-cooperative iris recognition. International Journal of Biometrics. 2012; 4(4):406-21.

[8] Beleza S, Johnson NA, Candille SI, Absher DM, Coram MA, Lopes J, Campos J, Araújo II, Anderson TM, Vilhjálmsson BJ, Nordborg M. Genetic architecture of skin and eye color in an African-European admixed population. PLoS Genet. 2013; 9(3):e1003372.

[9] Badejo JA, Majekodunmi TO, Atayero AA. Development of CUiris: A Dark-Skinned African Iris Dataset for Enhancement of Image Analysis and Robust Personal Recognition. World Congress on Engineering and Computer Science, San Francisco, USA. 2011; 624629

[10] Tisse CL, Martin L, Torres L, Robert M. Person identification technique using human iris recognition. In Proc. Vision Interface 2002 May 27; 2002. p. 294-299.

[11] Daugman J. Recognising persons by their iris patterns. In Advances in Biometric Person Authentication. Springer Berlin Heidelberg. 2004. p. 5-25.

[12] Arivazhagan S, Ganesan L, Srividya T. Iris recognition using multi-resolution transforms. International Journal of Biometrics. 2009; 1(3):254-67.

[13] Lu Y, He X, Wen Y, Wang PS. A new cow identification system based on iris analysis and recognition. International Journal of Biometrics. 2014; 6(1):18-32.

[14] Pankanti S, Bolle RM, Jain A. Biometrics: The future of identification [Guest Eeditors' Introduction]. Computer. 2000; 33(2):46-9.

[15] Liu S, Silverman M. A practical guide to biometric security technology. IT Professional. 2001; 3(1):27-32.

[16] Bowyer KW, Hollingsworth KP, Flynn PJ. A survey of iris biometrics research: 2008-2010. In Handbook of iris recognition. Springer London; 2013. p. 15-54.

[17] Granger E, Khreich W, Sabourin R, Gorodnichy DO. Fusion of biometric systems using Boolean combination: an application to iris-based authentication. International Journal of Biometrics. 2012; 4(3):291-315.

[18] Dey S, Samanta D. Fast and accurate personal identification based on iris biometric. International Journal of Biometrics. 2010; 2(3):250-81.

[19] Latha L, Thangasamy S. Efficient method of person authentication based on fusion of best bits in left and right irises. International Journal of Biometrics. 2012; 4(3):203-19.

[20] Sulochana CH, Selvan S. Robust iris recognition algorithm for non-cooperative environment. International Journal of Biometrics. 2009; 2(1):71-86.

[21] El-Abed M, Giot R, Hemery B, Rosenberger C. Evaluation of biometric systems: A study of users' acceptance and satisfaction. International Journal of Biometrics. 2012; 4(3):265-90.

[22] Hanna KJ, Mandelbaum R, Mishra D, Paragano V, Wixson LE. A System for Non-Intrusive Human Iris Acquisition and Identification. In MVA 1996 Nov 12; 1996. p. 200-203.

[23] Boles WW, Boashash B. A human identification technique using images of the iris and wavelet transform.
IEEE transactions on signal processing. 1998; 46(4):1185-8.

[24] Lim S, Lee K, Byeon O, Kim T. Efficient iris recognition through improvement of feature vector and classifier. ETRI journal. 2001; 23(2):61-70.

[25] Ma L, Wang Y, Tan T. Iris recognition based on multichannel Gabor filtering. InProc. Fifth Asian Conf. Computer Vision 2002 Jan 23; 2002; 1: 279-283.

[26] Miyazawa K, Ito K, Aoki T, Kobayashi K, Nakajima H. A phase-based iris recognition algorithm. In International Conference on Biometrics. Springer Berlin Heidelberg; 2006. p. 356-365

[27] Sanchez-Avila C, Sanchez-Reillo R. Two different approaches for iris recognition using Gabor filters and multiscale zero-crossing representation. Pattern Recognition. 2005; 38(2):231-40.

[28] Monro DM, Rakshit S, Zhang D. DCT-based iris recognition. IEEE Transactions on Pattern Analysis and Machine Intelligence. 2007; 29(4):586-95.

[29] Vatsa M, Singh R, Noore A. Improving iris recognition performance using segmentation, quality enhancement, match score fusion, and indexing. IEEE Transactions on Systems, Man, and Cybernetics, Part B (Cybernetics). 2008; 38(4):1021-35.

[30] Vatsa M, Singh R, Noore A. Reducing the False Rejection Rate of Iris Recognition Using Textural and Topological. Int. J. Signal Proc. 2005; 2(2).

[31] Ghassan J, Mohammed HB, Ann A. A new localization algorithm for iris recognition. Information Technology Journal. 2009; 8(2):226-30.

[32] Kohli N, Yadav D, Vatsa M, Singh R. Revisiting iris recognition with color cosmetic contact lenses. In2013 International Conference on Biometrics (ICB) 2013 Jun 4; IEEE. 2013. p. 1-7.

[33] Sarhan AM. Iris Recognition Using Discrete Cosine Transform and. Journal of Computer Science. 2009; 5(5):369-73.

[34] De Villar JA, Ives RW, Matey JR. Design and implementation of a long range iris recognition system. In 2010 Conference Record of the Forty Fourth Asilomar Conference on Signals, Systems and Computers. IEEE. 2010. p. 1770-1773.

[35] Kadry S, Smaili M. Wireless attendance management system based on iris recognition. Scientific Research and Essays. 2013; 5(12):1428-35.

[36] Abdullah M, Al-Dulaimi F, Al-Nuaimy W, Al-Ataby A. Efficient small template iris recognition system using wavelet transform. International Journal of Biometric and Bioinformatics. 2011; 5(1):16-27.

[37] Cho ES, Caytiles RD, Kim SS. New Algorithm Biometric-Based Iris Pattern Recognition System: Basis of Identity Authentication and Verification. Journal of Security Engineering. 2011; 8(5).

[38] Chaudhary U, Mubarak CM. Iris Recognition Using BPNN Algorithm', International Journal of Engineering Research and Applications (IJERA), National Conference on Emerging Trends in Engineering \& Technology, 2012; pp.203-208. 
[39] Memane MM, Ganorkar SR. RED Algorithm based Iris Recognition. genetics. 2012; 1:2.

[40] Verma P, Dubey M, Verma P, Basu S. Daughman's algorithm method for iris recognition-a biometric approach. International Journal of Emerging Technology and Advanced Engineering. 2012; 2(6):177-85.

[41] Han WY, Chen WK, Lee YP, Wu KS, Lee JC. Iris recognition based on local mean decomposition. Appl. Math. 2014; 8(1L):217-22.

[42] Khan YD, Khan SA, Ahmad F, Islam S. Iris recognition using image moments and k-means algorithm. The Scientific World Journal. 2014; 2014: 1-9.
[43] Li Y, Tao C. (2014). Iris Recognition Based on Improved Compressive Sensing Algorithm. Journal of Information \& Computational Science. [cited 2016 September 4]; 5349-5355. Available from: http://www.joics.com;

[44] Rakate NT, Patil UA. An Efficient Iris Recognition System using Dual-tree Complex Wavelet Transform. International Journal of Computer Science and Information Technologies. 2014; 5(3): 2749-2754

[45] Sun J, Lu ZM, Zhou L. Iris Recognition using curvelet transform based on principal component analysis and linear discriminant analysis. J Inf Hiding Multimedia Signal Process. 2014; 5(3):567-73. 